Means and Purposes:

\title{
A Suggestion to Our Members and Friends
}

One of the objects of the Bibliographical Society of Canada is to promote the study of bibliography and the publication of works of bibliography with a principal emphasis on those connected with Canada. We should like to suggest to our members, and to all those sympathetic to our aims and purposes, that the work of the Bibliographical Society of Canada can be supported by funds additional to membership fees. For example, you are urged to include the Society as a beneficiary when preparing your will. The following form is suggested:

I give, devise, and bequeath to the Bibliographical Society of Canada the sum of _ which shall be held by the Society as an endowment, the income from said endowment to be used for such of the Society's purposes as its Council in its discretion may determine.

The Bibliographical Society of Canada is a registered Canadian Charitable Organization (BN 89246-I443-Roor) and is authorized to issue official receipts for gifts, which may be used by donors to claim deductions in computing their taxable income. The President or Treasurer of the Society will be happy to discuss these matters with interested persons. 


\section{'Qui veut la fin veut les moyens'}

Un des objectifs de la Société bibliographique du Canada est de favoriser l'étude de la bibliographie et d'encourager la publication d'ouvrages bibliographiques, en particulier ceux qui se rapportent au Canada. La société aimerait suggérer à ses membres et à tous ceux qui sympathisent avec ses buts et objectifs d'appuyer financièrement ses entreprises, non seulement par la cotisation annuelle, mais aussi par des dons, qui peuvent même prendre la forme de legs. Dans ce dernier cas, la formulation suivante peut servir de modèle :

Je lègue à la Société bibliographique du Canada la somme de laquelle formera un capital dont les intérêts seront utilisés pour la poursuite de l'un ou l'autre des objectifs de la société selon ce que le conseil de ladite société déterminera.

De plus, la Société bibliographique du Canada est un organisme de charité enregistré (BN 89246-I443-RooI) et est ainsi autorisée à émettre des reçus pour fins d'impôt. Le président ou le trésorier de la société seront heureux de discuter de la question des dons avec les personnes intéressées. 